exhibition of remarkable manifestations associated with the youth of both sexes from time to time. Eventually they have, as a rule, been attributed to imposture. Among the best known is the Cock Lane Ghost in the middle of the eighteenth century, which inspired one of Andrew Lang's more intellectually agile efforts and is represented in the exhibition by an anonymous pamphlet attributed to Oliver Goldsmith. Another case, equally famous, if more materialistic in its supposed manifestation, was that of Mary Toft (1726) who gave birth to 27 rabbits, but failed to be equally prolific when removed from Guildford to Leicester Fields. In tracing back the history of the investigation of spirits, and of trials for witchcraft, it is remarkable what degree of credence was given to the evidence of juvenile neuropaths, and how frequently it was accepted as adequate, often without corroboration, to ensure condemnation of the accused to prison and death, while at the close of the sixteenth century the case of one Somers discussed in "A Discovery of the Fraudulent Practices of John Darrel ..." by Samuel Harsnett, an eminent divine and later Archbishop of York, was near to causing a schism in the Church.

\section{Exhibition of Antiquities from Colchester}

A special exhibition of antiquities from Colchester opened at the British Museum on December 10. The objects exhibited illustrate the results of the five years' exploration carried out on the British and Roman site at Colchester by the Colchester Excava. tion Committee, which was formed in 1930 by the British Museum and the Essex and Colchester Museum jointly. The exhibits, which consist of objects obtained by excavation, and plans, drawings and photographs, while giving a general view of the results, serve particularly to illustrate three aspects of the information which five years' work has made it possible to piece together. The first of these is the history of the site, beginning with its first foundation as a British city, then in its period of greatest prosperity under Cunobelinus (A.D. 5), its conquest at the time of the invasion of Claudius (A.D. 43), and its eclipse on the rise of the Roman eity seven years later. Apparently the diminished British city shared the fate of the Roman city when the latter was burned by Boudicca in A.D. 61. The photographs of the structural remains discovered and their plans, as well as the series of coins and material remains, are an index of the vicissitudes of the site. The second aspect is the character of native culture at Camulodunum; and the third, the effect of the impact of Roman culture on that of the native. To some, this last will appeal as of the greatest interest of all. Many new facts, indeed, have been brought to light at Colchester, not the least important being the data bearing upon the manufacture of Romano-British pottery. The remarkable discovery of the now famous kiln demonstrated that not only did the RomanoBritish potters make jugs, mortars, etc. in buff ware, slip coated fabric, castor ware, etc., but they also made the well-known Samian or 'terra sigillata' of which the manufacture had previously been thought to be confined to Gaul.

\section{Archæological Investigations in Ireland}

Dr. O'NeILl Hencken, director of the Harvard Archæological Mission to Ireland, before leaving for a brief vacation in America, has given an account of the results achieved in the recently completed third year of the Mission's work, which appears in the Observer of December 9. Excavations at Cushenden, Co. Antrim, would seem to have confirmed fully the view of the importance of this site for the elucidation of the origin and affinities of the stone age industries of north-east Ireland, which is held by Mr. C. Blake Whelan, with whom the Mission has been in co. operation. Mr. Whelan has recently pointed out the probability that further systematic investigation of stone age sites in this area would provide evidence of stratification, which is lacking for certain of the comparable European industries of the mesolithic and earlier phases of the neolithic ages (see Nature, Nov. 4, p. 702). From Dr. Hencken's statement, it now seems that this evidence is likely to be forthcoming from Cushenden, when certain comparative studies now in progress have been completed. He states that all the phases of the Irish stone age have been found at Cushenden in conditions, geological and other, which should provide the necessary data for the discussion of the origin of these cultures and their affinities with comparable material from sites in Britain and on the Continent.

Dr. Hencken also referred to the Mission's investigations on the crannog site of Lagore, Co. Meath, known from the annals to have been the residence of Irish kings in the eighth, ninth and tenth centuries. The excavations have shown that the site was occupied from much earlier times and have brought to light a wealth of material illustrating Irish culture in earlier centuries. The crannog is $150 \mathrm{ft}$. in diameter and $11 \mathrm{ft}$. thick. It was surrounded by an oaken palisade. The lake in which it stood has now disappeared. The inhabitants were pastoralists, but practised occasional hunting. Few, if any, traces were found of agricultural activity. Ornaments of bone and objects of leather, predominating in number, bear this out. Other materials in use were bronze, iron, glass (beads), enamel, wood, stone and pottery. The Mission has received generous assistance from the Irish Government.

\section{Medical Uses of Radium}

A REPort bearing the above title has been issued by the Medical Research Council summarising the results of research work during 1933 in the treatment of cancer and other conditions (Spec. Rep. Series, No. 197. H.M. Stationery Office. 9d. net). The radium is lent by the Council to selected centres throughout Great Britain, and these furnish reports to the Radiology Committee. In cancer of the mouth, radium has proved a successful agent in the treatment of primary growths of the tongue, but when the glands are involved they are much less amenable. 